\title{
ENTREPRENEURIAL CAPITAL AND PRODUCTIVE EFFICIENCY: THE CASE OF THE SPANISH REGIONS
}

\author{
Paz RICO (D**, Bernardí CABRER-BORRÁS \\ Departamento de Análisis Económico, Universitat de València, \\ Avd. de los Naranjos, s/n 46022, Valencia, Spain
}

Received 08 October 2018; accepted 20 April 2019

\begin{abstract}
The aim of this paper is to analyse the interrelation between entrepreneurial capital and productive efficiency of the Spanish regions while verifying the importance that business dynamics and entrepreneurial activity have on regional economic growth. For this purpose, data are used from the seventeen Spanish regions during the period 2003-2016. A multi-equation model is estimated that enables the analysis, on the one hand, of the existence of a causal relationship between business dynamics and entrepreneurial activity and, on the other hand, of these variables on the total factor productivity. The results lead to the conclusion that the entrepreneurial activity and the net creation of companies have a positive effect on productive efficiency and can explain the differences in the economic growth of the regions. In addition, the stock of human capital, the promotion of innovation and the degree of technological innovation act as catalysts for the productive efficiency of the regions. Finally, the results verify the fulfilment of the Schumpeter effect by which entrepreneurial capital generates economic growth.
\end{abstract}

Keywords: economic growth, entrepreneurship, new businesses, total factor productivity, productive efficiency, panel data.

JEL Classification: J24, M13, 011, O47.

\section{Introduction}

It is well known that the Spanish business structure is dominated by small companies, considered by numerous studies as one of the causes of the low productivity of the Spanish economy (European Commission, 2017). Small companies tend to have a lower level of productivity than larger companies. This fact is mainly due to the effects of scale and to lower investment in research and development $(R \& D)$ that limits their ability to adopt new innovations. The reasons for the limited size of Spanish businesses are multiple and are related to the characteristics of the industrial fabric and institutional factors.

\footnotetext{
${ }^{\star}$ Corresponding author. E-mail: prico@uv.es
} 
According to the Banco de España (2015), the Spanish business dynamic, which is the process of creation, destruction and growth of companies, affects the level of prices, production and employment. Moreover, it determines the efficiency in the allocation of productive resources between sectors and businesses. There are several channels through which business dynamics affect macroeconomics. Firstly, in the short term, greater business dynamism favours market competition and therefore stimulates production growth and the generation of employment. Secondly, in the long term, it benefits the development, diffusion and adoption of new technologies, promoting the growth of productivity.

The economic literature considers the existence of a strong relationship between regional economic growth and the level of knowledge and innovation, concluding that the regions with a higher level of technological development and innovation present higher growth (Griliches \& Lichtenberg, 1984; Coe \& Helpman, 1995; Griliches, 1998; Jacobs, Nahuis, \& Tang, 2002; Guellec \& Van Pottelsberghe de la Potterie, 2004). However, knowledge by itself does not generate economic growth; there needs to be a channel to transform this knowledge into economic growth. In this sense, Braunerhjelm, Acs, Audretsch, and Carlsson (2010) point out that, in order to generate growth, innovations in new products or processes need entrepreneurs willing to assume the risk involved in launching new products or processes onto the market. Therefore, entrepreneurial capital is one of the factors that generate externalities that contribute to economic growth ${ }^{1}$.

Entrepreneurship is understood as the creation of new businesses but also the activity of introducing new products or new productive processes onto the market. In empirical studies, no clear agreement has been reached on how to measure entrepreneurship. Empirical studies use either the creation of businesses or the index of entrepreneurial activity as alternative measures of entrepreneurship. It is true that the activity of entrepreneurs involves, in most cases, the creation of businesses, thus establishing a link between entrepreneurship and business creation. In this sense, Acs (2006) considers that the creation of businesses generates jobs, intensifies competitiveness and promotes innovation. It is therefore common to use the creation of new businesses as an indicator of entrepreneurship (OECD, 2008; Carree \& Thurik, 2008; Koellinger \& Thurik, 2012; Van Praag \& Van Stel, 2013; Erken, Donselaar, \& Thurik, 2018). However, acknowledging the creation of businesses as the only entrepreneurial activity would overlook other important entrepreneurial contributions. For example, some studies use the index of entrepreneurial activity (Prieger, Bampoky, Blanco, \& Liu, 2016; Van Stel, Carree, \& Thurik, 2015; González-Pernía \& Peña-Legazkue, 2015; Acs, Estrin, Mickiewicz, \& Szerb, 2018). In this research, however, both variables, the creation of businesses and the index of entrepreneurial activity, will be considered together. The main contribution of this paper is that it considers both entrepreneurial activity and creation of businesses in explaining cross-regional differences in economic growth. Specifically, the net creation of companies will be used as a measure of regional business dynamics and the total entrepreneurial activity (TEA) index, provided by the Global Entrepreneurship Monitor (GEM), as a measure of regional entrepreneurship.

\footnotetext{
${ }^{1}$ In the words of Audretsch (2007), entrepreneurial activity is the missing link between investment in new knowledge and economic growth.
} 
In addition, the creation and destruction of businesses has a marked cyclical component because the creation of businesses is substantially greater in expansions than in recessions while the opposite occurs with the destruction of businesses (Banco de España, 2015). Based on these assumptions, a causal relationship between economic growth and net business creation is considered and, therefore, the endogeneity of this last variable as a determining factor for the economic growth of a region. In this sense, Aubry, Bonnet, and Renou-Maissant (2015) distinguish two opposing effects: the refugee effect, or push effect, according to which unemployment stimulates the creation of businesses and the Schumpeter effect by which entrepreneurial businesses reduce unemployment. These facts lead them to analyse the influence of new businesses on economic growth from two dimensions. The first is a regional dimension according to which entrepreneurship can be encouraged by the entrepreneurial environment of the region. The second is a macroeconomic dimension in which the existence of a push effect versus the Schumpeter effect can be identified. Thurik, Carree, Van Stel, and Audretsch (2008) consider both effects: the refugee effect and the entrepreneurial effect. Their empirical results, using data from 23 OECD countries, confirm the existence of both effects but the entrepreneurial effect is considerably stronger than the refugee effect. This paper also focuses on the fact that creation of companies is not exogenous. On the contrary, regional business dynamics depend on the economic growth, and the model specified will help identify what effect, push or Schumpeter, prevails.

One of the most relevant lines of research within the current economic literature is that which relates economic growth to entrepreneurship (Van Praag \& Versloot, 2007; Audretsch \& Peña-Legazkue, 2012; Acs et al., 2018; Blanco-Mesa, Gil-Lafuente, \& Merigó, 2018; Rico \& Cabrer-Borras, 2019). The basic idea is that entrepreneurship affects economic growth. However, there are a variety of ways to quantify economic growth. Currently, the most popular method is to quantify it through total factor productivity (TFP). The TFP is a fundamental variable to measure the growth and development of an economy since it reflects the productive efficiency with which its economic system works. For Krugman (1994) "productivity is not everything, but in the long term it is almost everything". The growth of productivity generates economic growth since technical progress leads to an increase in the yields of all productive factors, especially those of labour. Therefore, the growth capacity of an economy depends, fundamentally, on technical progress and this capacity is reflected in the rate of growth of the TFP (Vila, Cabrer-Borras, \& Pavia, 2015).

The aim of this paper is to analyse the interrelation between entrepreneurial capital, measured through business dynamics and the level of entrepreneurship, and the productivity of the Spanish regions. The purpose of analysing this interrelation is to verify if it can explain the divergences in the economic growth of the Spanish regions. To do this, a multi-equational model is specified that enables the estimation of the relationship between the net creation of businesses, entrepreneurship and TFP or productive efficiency. One of the advantages of using a model of simultaneous equations is that it avoids the problem of endogeneity.

This paper is divided into six sections. Following the introduction, the second section presents the theoretical framework. The third section presents the methodology used and the fourth section analyses the data used in the research. The fifth section shows the empirical results obtained and, finally, the last section includes the main conclusions of the paper. 


\section{Theoretical framework}

In his seminal article, Solow (1956) proposed a model known as the Solow residual to measure productivity growth based on two explicit factors, physical capital and labour, and an implicit factor, technological advance. Solow acknowledged that growth was influenced by technological change but considered it exogenous in the formalization of its production function. In fact, Solow considered that the productive factors, capital and labour, did not necessarily explain the growth variation, given that most of its variation was explained by the residual contained in technological progress.

Subsequently, the models of endogenous growth of Romer (1986) and Lucas $(1988,1993)$ explicitly introduced technological progress, considering that knowledge is transmitted through externalities and generates effects of drag on the economy. However, knowledge by itself does not generate economic growth; the externalities assumed to exist by Romer and Lucas must be produced. Entrepreneurship is one of the channels of knowledge transmission that contributes to economic growth. In this sense, Audretsch (2007) considers that the policy of promoting entrepreneurial activity promotes economic growth.

As indicated by Acs et al. (2018), the theory that there is a positive relationship between entrepreneurship and growth goes back to Schumpeter (1934). The literature attempting to show the existence of this positive relationship has been prolific since then. Wennekers and Thurik (1999) and, more recently, Carree and Thurik (2010) provide a review of the literature that includes the relationship between entrepreneurship and economic growth. From the empirical evidence obtained in the literature, it can be concluded that entrepreneurial capital, understood both as the creation of new businesses and entrepreneurial activity, are key factors in achieving an improvement in productivity and, therefore, generating economic growth. In this sense, Callejón and Segarra (1999) analyse the relationship between business dynamics and the growth of TFP and find evidence of a positive impact of business dynamics on TFP. Likewise, Holtz-Eakin and Kao (2003) quantify the linkage between productivity growth and entrepreneurship, analysing the relationship between businesses' birth rates, death rates and productivity. They show that increases in the birth rates of businesses leads to higher levels of productivity. Audretsch and Keilbach (2004), Audretsch, Keilbach, and Lehmann (2006) and Audretsch and Keilbach, (2008) consider the rate of new business as a proxy for entrepreneurial capital and find that knowledge-intensive businesses increase economic growth. Van Stel et al. (2005) find the TEA of GEM to be directly correlated with growth in rich countries and inversely associated in low-income countries. Similarly, Prieger et al. (2016) use data from GEM and differentiate between developed and developing countries. They highlight that entrepreneurship in developing countries has a positive effect on growth while having no effect in developed countries.

Bjornskov and Foss (2013) argue that entrepreneurship, in the form of start-ups, influences TFP. Van Praag and Van Stel (2013) estimate extended versions of traditional Cobb-Douglas production functions of 19 OECD countries and they find robust evidence of an optimal business ownership rate. Moreover, they conclude the relationship between business ownership and macroeconomic productivity is stronger for countries with higher levels of education. Aubry et al. (2015) investigate the relationships between GDP, the unemployment rate and new-firm start-ups both in the short and long term with French data. 
Their evidence shows a range of interactions between new-firm start-ups, economic growth and employment.

González-Pernía and Peña-Legazkue (2015) understand entrepreneurship as the creation of new ventures and they use data from GEM. Their analysis leads them to conclude that export-oriented entrepreneurship has a positive influence on economic growth in the Spanish regions.

Erken et al. (2018) examine the role of entrepreneurship as a determinant of TFP. Entrepreneurship is computed as the number of business owners per workforce corrected for the level of economic development, and they find a stable and significant impact of entrepreneurship on TFP. Finally, Acs et al. (2018) investigate whether the combination of institutions and entrepreneurship, measured through the TEA of GEM, has an impact on economic growth. They conclude that there is an impact on economic growth by what they call an "entrepreneurial ecosystem".

Fritsch (2008) and Fritsch and Schroeter (2011) show that the effect of business creation is different between regions while Aubry et al. (2015) consider that entrepreneurial capital contributes in different ways to the growth of the regions of industrialized countries.

Based on the evidence that there is a positive relationship between entrepreneurial capital and economic growth, this research aims to verify the existence in Spain of a causal relationship between entrepreneurship and the creation of businesses and of these variables with TFP. This, in turn, should confirm the importance of business dynamics and entrepreneurial activity in regional economic development and explain the differences in economic growth between regions.

\section{Methodology}

There are different approaches for obtaining TFP and one of them is based on growth accounting. According to this methodology, the growth of TFP is obtained as part of the endogenous growth of the production that is not explained by the inputs used. Specifically, the methodology of growth accounting decomposes the growth of production into three sources: the growth of the labour factor, the growth of the capital factor and the growth of the TFP 2 (Audretsch \& Keilbach, 2004).

The accounting approach to the decomposition of growth sources begins by considering a production function. The most used production function is the Cobb and Douglas (1928), which is specified as follows:

$$
Y_{i t}=A_{i t} K_{i t}^{\alpha} L_{i t}^{\beta},
$$

where: $Y_{i t}$ is the output level or production in real terms, $A_{i t}$ measures the technological advance or productive efficiency, $K_{i t}$ is the physical capital stock, $L_{i t}$ is the employment level, whilst $\alpha$ is the elasticity of production for the factor labour and $\beta$ the elasticity of production for the factor capital.

\footnotetext{
${ }^{2}$ As indicated in the previous section, under the neoclassical hypothesis, the growth of the TFP reflects unincorporated technological progress. However, in practice, the growth of TFP is obtained as a residual that also includes improvements in the efficiency of productive inputs.
} 
Taking logarithms from equation (1), and assuming constant returns to scale, $\alpha+\beta=$ 1, is obtained:

$$
\ln Y_{i t}=\ln A_{i t}+\alpha \ln K_{i t}+(1-\alpha) \ln L_{i t} .
$$

When taking first differences, the following relationship is obtained:

$$
\Delta \ln Y_{i t}=\Delta \ln A_{i t}+\alpha \Delta \ln K_{i t}+(1-\alpha) \Delta \ln L_{i t} .
$$

Equation (3) indicates that the growth rate of production is determined by the growth of physical capital, employment, and the improvement of efficiency or increase in TFP. In this way, the increase of the TFP would be obtained as:

$$
\Delta \ln A_{i t}=\Delta \ln Y_{i t}+\alpha \Delta \ln K_{i t}-(1-\alpha) \Delta \ln L_{i t} .
$$

According to Cuadrado and Moral (2016), the coefficient $\alpha$ refers to the arithmetic mean of the share of labour income in production in period $t$ and $t-1$. As indicated by Cuadrado and Moral (2016), the temporal variability of the elasticity of production to the labour factor is usually ignored and assumed to be a constant elasticity equal to 0.65 . In this paper, the elasticity of the labour factor is calculated over the sample period and for each of the regions. From this calculation, the growth of the TFP for each region is obtained.

As indicated above, both the creation of new businesses and entrepreneurship affect development and economic growth. Likewise, economic growth is expected to stimulate the creation of new opportunities and, therefore, the creation of businesses and entrepreneurial activity. This paper makes the distinction between the creation of new businesses, which has traditionally been used as an indicator of entrepreneurship, and the rate of entrepreneurial activity, which has been used in other studies as an indicator of the entrepreneurship of the population of each region. According to Audretsch and Keilbach (2004), a high rate of creation of new businesses has an overall effect on economic activity and especially on entrepreneurial activity.

In addition, there are other variables or exogenous factors that influence the growth of TFP, such as human capital, $R \& D$ expenditure and the intensity of innovative activity in each region.

The exogenous variable human capital is one of the factors most used in growth models. Citations include, among others, contributions made by Becker (1975), Mincer (1984), Romer (1986), Barro (1991), Barro and Lee (1993), Barro (2001), Barro and Sala-i-Martin (2004). Another train of economic thought relates human capital with the creation of businesses and technological diffusion. This approach is seen in a number of contributions, among which are Sevilir (2010), Kato and Honjo (2015) and Vila et al. (2015).

The second of the exogenous variables, which determines both the growth of productivity as well as the creation of businesses and entrepreneurship, is R\&D expenditure made by each of the regions. In the relevant literature, there is both theoretical and empirical evidence that corroborates the contribution of investment in R\&D to economic growth (Griliches \& Lichtenberg, 1984; Coe \& Helpman, 1995; Griliches, 1998; Jacobs et al., 2002; Guellec \& Van Pottelsberghe de la Potterie, 2004; Aghion, 2017). 
The third exogenous variable considered is innovation. According to Rodriguez-Pose and Comptour (2012), innovative activity can be quantified through the number of patents in each of the regions.

In this paper, in order to collect the interrelation between the variables, a multi-equation model has been specified and estimated instead of using a single-equation model or reduced-model. In addition, the estimators in the former are generally more efficient than those obtained in the latter.

In the first equation, the explanatory variables used for explaining TFP growth are the net creation of businesses $(\Delta \mathrm{F})$, expenditure in $\mathrm{R} \& \mathrm{D}(\Delta \mathrm{R} \& \mathrm{D})$, human capital $(\Delta \mathrm{HK})$ and innovation $(\triangle \mathrm{PAT})^{3}$ :

$$
\Delta \mathrm{TFP}=\mathrm{f}(\Delta \mathrm{F}, \Delta \mathrm{R} \& \mathrm{D}, \Delta \mathrm{HK}, \Delta \mathrm{PAT}) .
$$

In the second equation, the explanatory variables used for explaining the net creation of businesses are entrepreneurship (TEA), growth of TFP and expenditure on $\mathrm{R} \& \mathrm{D}^{4}$ :

$$
\Delta \mathrm{F}=\mathrm{f}(\mathrm{TEA}, \Delta \mathrm{TFP}, \Delta \mathrm{R} \& \mathrm{D}) .
$$

In the third equation, the explanatory variables used for explaining entrepreneurship or TEA are its own past value (TEA $(-1))$, as a factor of inertia, the creation of new businesses and the expenditure on $\mathrm{R} \& \mathrm{D}$ :

$$
\mathrm{TEA}=\mathrm{f}(\mathrm{TEA}(-1), \Delta \mathrm{F}, \Delta \mathrm{R} \& \mathrm{D}) .
$$

The system is specified by the following three behaviour equations:

$$
\begin{aligned}
& \Delta \mathrm{TFP}_{i t}=\alpha_{1}+\alpha_{2} \Delta \mathrm{F}_{i t}+\alpha_{3} \Delta \mathrm{R}_{2} \mathrm{D}_{i t}+\alpha_{4} \Delta \mathrm{HK}_{i t-1}+\alpha_{5} \Delta \mathrm{PAT}_{i t}^{2}+u_{1 i t} \\
& \Delta \mathrm{F}_{i t}=\beta_{1}+\beta_{2} \mathrm{TEA}_{i t}+\beta_{3} \Delta \mathrm{TFP}_{i t-1}+\beta_{4} \Delta \mathrm{R} \mathrm{D}_{i t}+u_{2 i t} ; \\
& \mathrm{TEA}_{i t}=\gamma_{1}+\gamma_{2} \mathrm{TEA}_{i t-1}+\gamma_{3} \Delta \mathrm{F}_{i t}+\gamma_{4} \Delta \mathrm{R} \mathrm{D}_{i t}+u_{3 i t} .
\end{aligned}
$$

The specification of this multi-equational model allows analysis of the following causal chain: the promotion of knowledge and the creation of new businesses play a fundamental role in the entrepreneurial activity. At the same time, entrepreneurial activity and the promotion of knowledge generate an increase in the number of businesses. Finally, the creation of new businesses together with investment in human capital and the promotion of knowledge and innovation determine the behaviour of the productive efficiency of the economy (see Figure 1). Consideration of this causal chain is different with respect to other studies on the subject as the latter do not take into account the interrelation between these three variables.

Given the possible problems of simultaneity or endogeneity between the three variables shown in Figure 1, the model has been estimated using different methods that overcome the econometric problem of inconsistency of the estimators. It should be noted that, in general, in the case of endogeneity of the explanatory variables, the least squares estimators provide inconsistent estimators.

\footnotetext{
${ }^{3}$ All the exogenous variables of the equation are in first differences since the endogenous variable is the rate of variation of the TFP.

4 All the variables are in first differences except TEA because it is a stationary variable.
} 


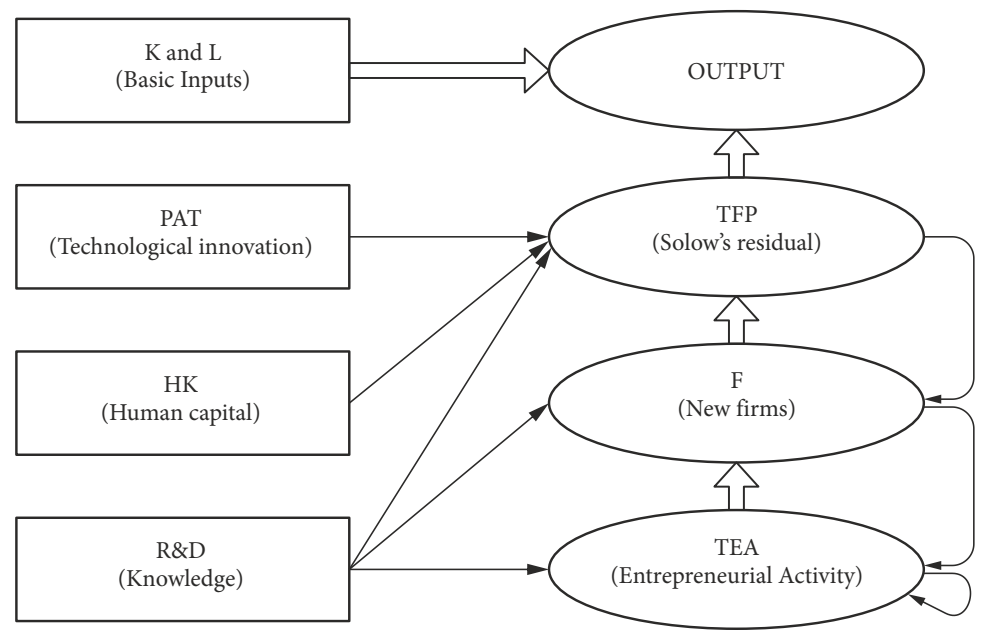

Figure 1. Scheme of the interrelationships of the proposed model

(source: compiled by the authors from the system specification of the equations $8 \mathrm{a}, 8 \mathrm{~b}$ and $8 \mathrm{c}$ )

\section{Data and the variables selected}

The data used in this analysis come from different institutions, both public and private. The National Institute of Statistics (INE) has provided information on the level of output, quantified through the Gross Domestic Product (GDP) in constant euros for each of the regions, expressed in thousands of euros. The same source has been used to obtain information on the number of inhabitants of each region over the period 2000-2016. In addition, the 17 Spanish regions have been considered as study units.

The information on the labour production factor is obtained from the INE, using as its measurement the number of workers, expressed in thousands. The data used for the other basic production factor, the stock of physical capital, comes from the BBVA-IVIE Foundation. The source of the stock of human capital comes from the estimates made by the BBVA-IVIE Foundation while the R\&D expenditure per inhabitant and the number of patents per GDP of each region for each year of the sample period are provided by the INE.

The number of businesses in each year has been obtained from the Central Companies Directory (Directorio Central de Empresas, DIRCE). The difference in the number of businesses between two consecutive years is considered as an indicator of the net creation of businesses for each region. In order to take into account the size of each region, this variable has been divided by the population, obtaining the net creation of companies per capita in each region, as proposed by Audretsch and Keilbach (2007).

Likewise, the indicator of entrepreneurial activity comes from GEM which, based on an annual survey, provides the percentage of entrepreneurial activity of the adult population of the region or country. The data cover the period 2003-2016, which means that the sample period of the research covers the same period.

In relation to productivity, as indicated in the previous section, first the elasticity of the labour factor over time and for each of the regions is calculated. Secondly, the results of the elasticity of the labour factor are applied to the calculation of the growth of the TFP, for each 
region, through equation (4) of the previous section. In summary form, Table 1 presents the definitions and sources of the variables used.

Figure 2 shows the average TEA of each region for the period 2003-2016. From Figure 2, it can be concluded that Catalonia is the region with the highest average level of entrepreneurship while Asturias is the region with the lowest TEA. When comparing this graph with the average growth of the GDP (see Figure 3), it can be seen that the regions with lower TEA, such as Asturias, have lower growth rates and also their recovery following the economic crisis has been lower than other regions, such as Catalonia or the Balearic Islands which have higher rates of entrepreneurial activity. Figure 4 shows that the average variation of the businesses during the sample period has also been very uneven among the regions.

Table 1. Definition and sources of the variables used (source: compiled by the authors)

\begin{tabular}{|l|l|}
\hline $\mathrm{HK}_{i t}$ & $\begin{array}{l}\text { Human capital. Percentage of workers who have completed their studies at different } \\
\text { levels of education, by region and year. Source: IVIE }\end{array}$ \\
\hline $\mathrm{K}_{i t}$ & Stock of Physical Capital, by region and year. Source: BBVA Foundation-IVIE \\
\hline $\mathrm{L}_{i t}$ & Labour. Number of workers, in thousands, of people by region and year. Source: INE \\
\hline $\mathrm{F}_{i t}$ & $\begin{array}{l}\text { Number of companies divided by population, by region and year. } \\
\text { Source: DIRCE and INE }\end{array}$ \\
\hline $\mathrm{PAT}_{i t}$ & $\begin{array}{l}\text { Technological innovation. Number of patents divided by GDP, by region and year. } \\
\text { Source: INE and OEPM (Spanish Patent and Trademark Office })\end{array}$ \\
\hline $\mathrm{TFP}_{i t}=\ln \mathrm{A}_{i t}$ & $\begin{array}{l}\text { Productive efficiency. Total Factor Productivity, by region and year. } \\
\text { Source: INE and BBVA Foundation-IVIE. Compiled by authors from equation (4) }\end{array}$ \\
\hline${\mathrm{R} \& \mathrm{D}_{i t}}$ & $\begin{array}{l}\text { Investment in knowledge. R\&D expenses per inhabitant, by region and year. } \\
\text { Source: INE }\end{array}$ \\
\hline $\mathrm{TEA}_{i t}$ & Total Entrepreneurial Activity, by region and year. Source: GEM \\
\hline $\mathrm{Y}_{i t}$ & $\begin{array}{l}\text { Output. Gross domestic product, in thousands of constant euros, by region and year. } \\
\text { Source: INE }\end{array}$ \\
\hline
\end{tabular}

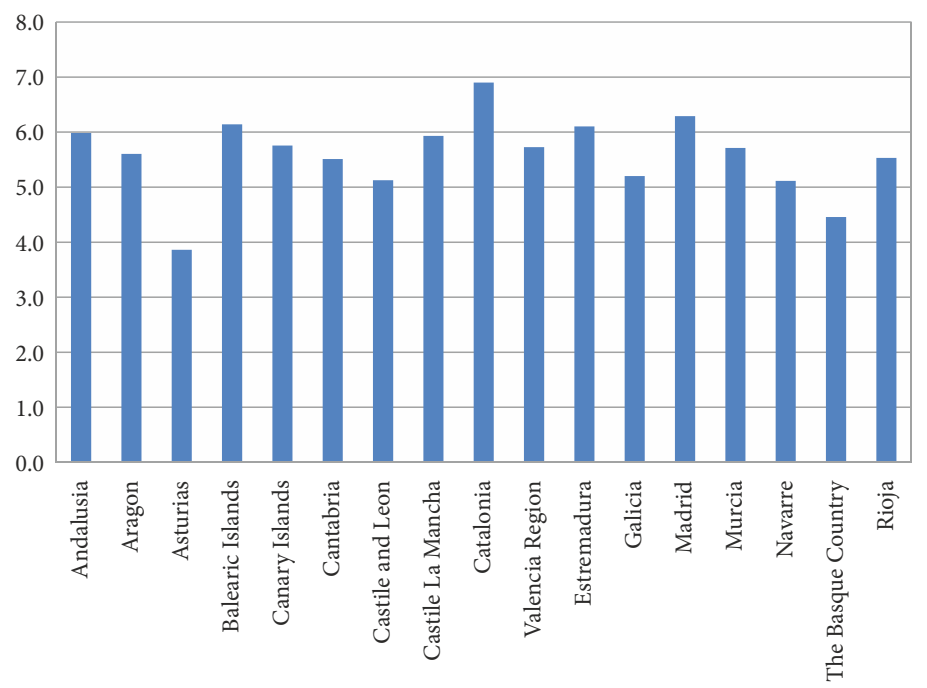

Figure 2. TEA average for the period 2003-2016 (source: compiled by the authors from the GEM)

\footnotetext{
${ }^{5}$ Registro de la Propiedad Industrial, Oficina Española de Patentes y Marcas.
} 


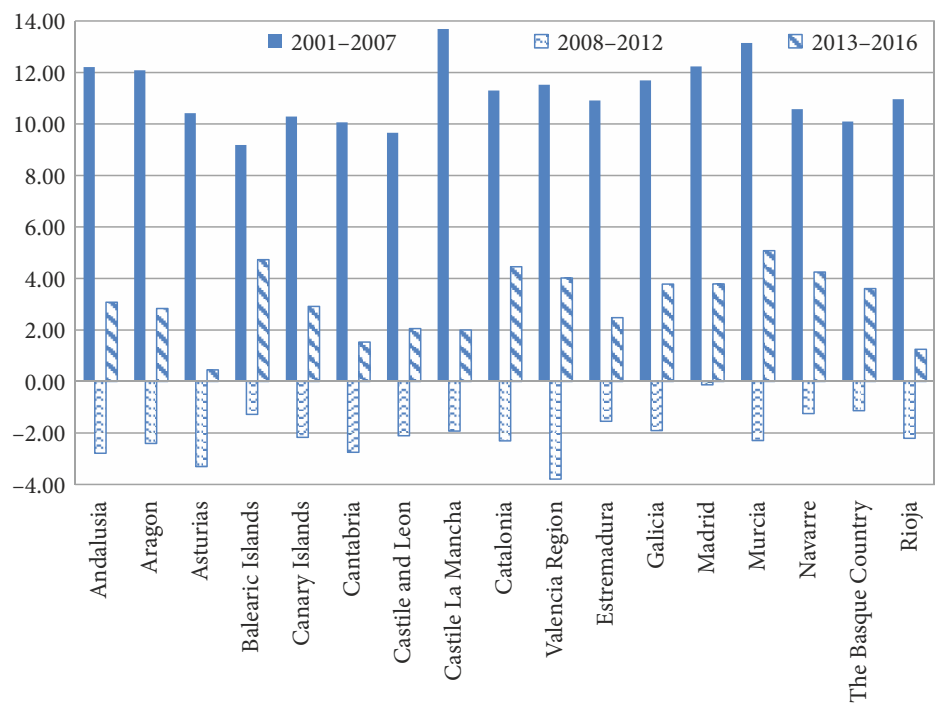

Figure 3. Average growth of GDP (source: compiled by the authors from the INE)

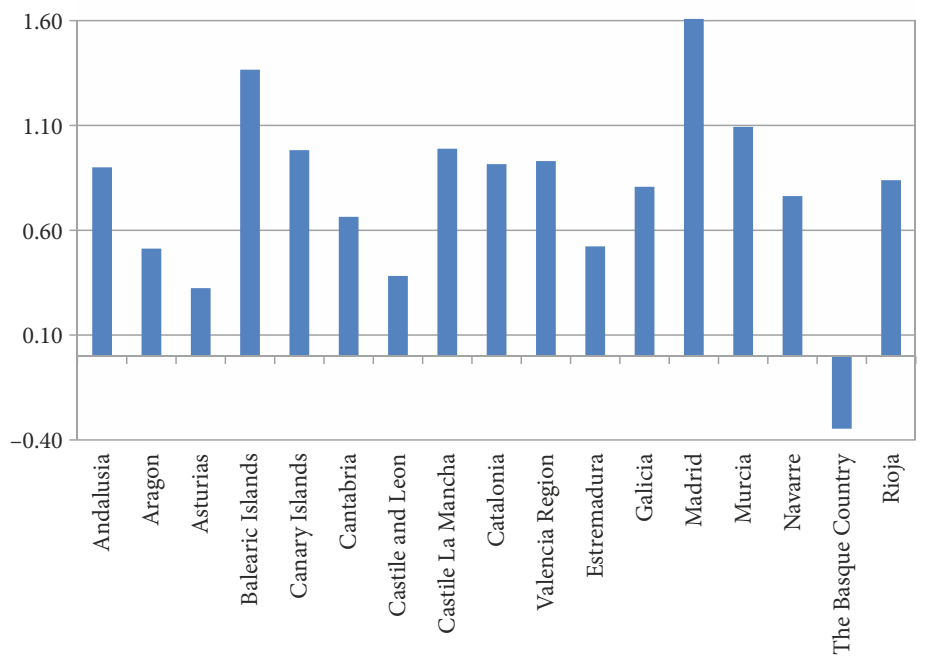

Figure 4. Average variation of businesses for every 1000 inhabitants during the period 2003-2016 (source: compiled by the authors from the DIRCE)

\section{Empirical results}

The system defined by equations ( $8 \mathrm{a}, 8 \mathrm{~b}$ and $8 \mathrm{c}$ ) is applied to 17 regions over fourteen years which configures a data panel of 238 observations. The aim of the analysis is to study the interrelation between entrepreneurial activity, creation of firms and economic growth. This interrelation may explain the differences between regional economic growth. However, from the empirical point of view and in order to avoid the possible problems of multicollinearity among the explanatory variables, the Solow residual is used as an objective variable instead of the output level of the economy. 
The three equations that define the dynamic system interrelate entrepreneurial activity, the net creation of companies and economic growth (see Figure 1). Thus, in equation (8a) the creation of companies is linked to the growth of TFP. Equation (8b) relates the growth of the TFP and the creation of companies with entrepreneurial activity. Finally, in equation (8c), a causal relationship is established between the creation of new companies and entrepreneurial activity. Before commenting on the results, the following points about the proposed model should be noted:

1. The specified system is dynamic since the past value of endogenous variable of the first equation acts as an explanatory variable in the second equation.

2. The data used make up a data panel constituted by the annual data of the 17 Spanish regions.

3. The three equations of the system are interrelated since there are common variables in all of them.

In this case, in order to capture the fixed effects, both the estimation of the system by Least Squares (LS) and the estimation by Dummies Variables Least Squares (DVLS) provide biased and inconsistent estimators.

In order to overcome endogeneity problems, each of the equations are estimated in an isolated way by means of Two Stages Least Squares (2SLS) and, alternatively, by Generalized Method of Moments (GMM). However, when estimating each of the equations individually, the estimators obtained are inefficient. Nevertheless, asymptotically efficient estimators of the system can be obtained simultaneously by means of the Three-Step Least Squares (3SLS) method.

Consequently, the system is estimated using two different strategies. The first is to estimate the system equation by equation while the second is to estimate all the equations of the model simultaneously. Due to the problem of heteroscedasticity caused by the diversity of the Spanish regions, the White method is used in order to guarantee the efficiency of the estimators.

The results indicate that the differences between the estimation by LS and DVLS are not significant. But, in addition, the LS estimators are seen to provide a better goodness of fit than those obtained by DVLS, as indicated in Table 2. However, the results obtained by 2SLS and GMM provide biased and consistent estimators. In addition, the estimators obtained by these methods are not efficient since they ignore the interrelation between the different equations. Ultimately, the system is estimated jointly by the 3SLS method in order to obtain consistent and asymptotically efficient estimators. Furthermore, comparing the results obtained by the 2SLS, GMM and 3SLS methods, it can be concluded that the estimators are robust as the differences in the results obtained between the different estimation methods are not significant (see Table 3).

The estimations obtained confirm that all the variables included in the three equations of the system that determine the economic growth, the creation of businesses and the entrepreneurial activity are highly significant; they present the appropriate signs and, in addition, offer robust estimators. It is worth noting the role played by $\mathrm{R} \& \mathrm{D}$ expenditure in all the equations (see Table 3). 
Table 2. Results of the multi-equation model by LS and DVLS

\begin{tabular}{|c|c|c|c|c|c|}
\hline \multirow{2}{*}{$\begin{array}{l}\text { Endogenous } \\
\text { Variables }^{(1)}\end{array}$} & \multirow{2}{*}{$\begin{array}{l}\text { Explanatory } \\
\text { Variables }\end{array}$} & \multicolumn{2}{|c|}{ LS } & \multicolumn{2}{|c|}{ Fixed Effects DVLS } \\
\hline & & Coefficient & t-Statistic & Coefficient & t-Statistic \\
\hline \multirow{6}{*}{$\Delta \mathrm{TFP}_{i t}$} & constant & 0.001 & 0.176 & & \\
\hline & $\Delta \mathrm{F}_{i t}$ & $0.126^{\star * *}$ & 10.675 & $0.127^{\star \star *}$ & 10.947 \\
\hline & $\Delta \mathrm{R} \& \mathrm{D}_{i t}$ & $0.050^{\star * *}$ & 6.626 & $0.049^{* * *}$ & 6.182 \\
\hline & $\Delta \mathrm{HK}_{i t-1}$ & $0.058^{\star \star *}$ & 3.176 & $0.065^{\star \star \star}$ & 3.639 \\
\hline & $\Delta \mathrm{PAT}_{i t}^{2}$ & 0.015 & 0.475 & 0.021 & 0.743 \\
\hline & Dummy region & No & & Yes & \\
\hline \multirow{5}{*}{$\Delta \mathrm{F}_{i t}$} & constant & $-0.001^{\star *}$ & -2.240 & & \\
\hline & $\mathrm{TEA}_{i t}$ & $0.016^{* *}$ & 2.268 & 0.008 & 1.054 \\
\hline & $\Delta \mathrm{TFP}_{i t-1}$ & $0.021^{\star \star \star}$ & 8.320 & $0.022^{\star * \star}$ & 8.987 \\
\hline & $\Delta{\mathrm{R} \& \mathrm{D}_{i t}}$ & $0.013^{\star * *}$ & 3.469 & $0.015^{\star * *}$ & 4.020 \\
\hline & Dummy region & No & & Yes & \\
\hline \multirow{5}{*}{$\mathrm{TEA}_{i t}$} & constant & $0.305^{\star \star *}$ & 8.582 & & \\
\hline & $\mathrm{TEA}_{i t-1}$ & 0.005 & 0.928 & 0.006 & 1.177 \\
\hline & $\Delta \mathrm{F}_{i t}$ & $0.040^{\star * \star}$ & 6.256 & $0.023^{\star \star \star}$ & 3.396 \\
\hline & $\Delta{\mathrm{R} \& \mathrm{D}_{i t}}$ & $0.143^{\star \star \star}$ & 4.508 & $0.175^{\star \star \star}$ & 5.511 \\
\hline & Dummy region & No & & Yes & \\
\hline \multicolumn{2}{|c|}{ Determinant residual covariance } & $2.58 \mathrm{E}-11$ & & $2.02 \mathrm{E}-11$ & \\
\hline \multicolumn{2}{|c|}{ Akaike Information Criteria } & -4143.609 & & -4101.538 & \\
\hline \multicolumn{2}{|c|}{ Number of observations } & 221 & & 221 & \\
\hline
\end{tabular}

Notes: ${ }^{* * *}$ denote significance level at $1 \%{ }^{(1)}$ The White method is used in order to guarantee the efficiency of the estimators.

The results obtained from equation (8a), presented in Table 3, indicate that the TFP of each region is explained by the following factors: the net creation of businesses per inhabitant in each region; the promotion of knowledge measured by $R \& D$ expenditure per capita; the investment in human capital; and technological innovation quantified by the number of patents divided by the GDP of each region. The estimated parameters reveal that technological innovation, the promotion of knowledge and the stock of human capital contribute positively to the economic growth of the regions. Thus, it can be shown that technological innovation presents a positive sign and is highly significant. Similarly, the quality of the workforce, measured through human capital, has a significant and positive influence on TFP. According to Hanushek (2012) "an economy's ability to grow over time, its ability to innovate and raise both productivity and real incomes-is strongly tied to the quality of education provided to the vast majority of workers. Skills and intellectual capital are increasingly important in a modern economy, and schools play a central role in the development of valuable skills". In addition, the promotion of innovation, quantified by R\&D expenditure per capita of each region, contributes effectively to the increase in the productivity of the economy. Finally, the results obtained indicate that the creation of new businesses has a favourable and significant 
Table 3. Results of the multi-equation model by different methods of estimation

\begin{tabular}{|c|c|c|c|c|c|c|c|c|c|}
\hline \multirow{2}{*}{$\begin{array}{l}\text { Endogenous } \\
\text { Variables }^{(1)(2)}\end{array}$} & \multirow{2}{*}{$\begin{array}{c}\text { Explanatory } \\
\text { Variables }\end{array}$} & \multicolumn{2}{|c|}{ LS } & \multicolumn{2}{|c|}{ 2SLS } & \multicolumn{2}{|c|}{ GMM } & \multicolumn{2}{|c|}{3 SLS } \\
\hline & & Coefficient & t-Statistic & Coefficient & $\mathrm{t}$-Statistic & Coefficient & $\mathrm{t}$-Statistic & Coefficient & t-Statistic \\
\hline \multirow{5}{*}{$\Delta \mathrm{TFP}_{i t}$} & constant & 0.001 & 0.871 & -0.007 & -1.537 & $-0.008^{*}$ & -1.766 & $-0.008^{*}$ & -1.646 \\
\hline & $\Delta \mathrm{F}_{i t}$ & $0.126^{\star * *}$ & 7.364 & $0.158^{* * *}$ & 7.042 & $0149^{* * *}$ & 7.346 & $0.161^{\star * *}$ & 7.663 \\
\hline & $\Delta{\mathrm{R} \& \mathrm{D}_{i t}}$ & $0.050^{* * *}$ & 6.476 & $0.037^{* * *}$ & 3.186 & $0.041^{* * *}$ & 3.096 & $0.036^{* * *}$ & 3.559 \\
\hline & $\Delta \mathrm{HK}_{i t-1}$ & $0.058^{\star * *}$ & 4.318 & $0.071^{* * *}$ & 3.883 & $0.082^{* * *}$ & 4.29 & $0.074^{* * *}$ & 3.753 \\
\hline & $\Delta \mathrm{PAT}_{i t}^{2}$ & 0.015 & 0.911 & $0.163^{* *}$ & 1.828 & $0.155^{*}$ & 1.789 & $0.183^{* * *}$ & 2.058 \\
\hline \multirow{4}{*}{$\Delta \mathrm{F}_{i t}$} & constant & $-0.001^{* * *}$ & -2.531 & $-0.002^{* * *}$ & -2.283 & -0.002 & -1.578 & $-0.002^{* * *}$ & -2.532 \\
\hline & $\mathrm{TEA}_{i t}$ & $0.016^{* * *}$ & 2.719 & $0.040^{\star * *}$ & 2.188 & $0.028^{* *}$ & 1.704 & $0.040^{* * *}$ & 2.521 \\
\hline & $\Delta \mathrm{TFP}_{i t-1}$ & $0.021^{\star * *}$ & 11.643 & $0.018^{\star * *}$ & 6.721 & $0.019^{* * *}$ & 7.391 & $0.018^{* * *}$ & 5.895 \\
\hline & $\Delta \mathrm{R} \& \mathrm{D}_{i t}$ & $0.013^{\star * *}$ & 3.269 & $0.010^{* * *}$ & 2.353 & $0.011^{* * *}$ & 3.081 & $0.010^{* * *}$ & 2.516 \\
\hline \multirow{4}{*}{$\mathrm{TEA}_{i t}$} & constant & $0.305^{* * *}$ & 9.334 & $0.362^{* * *}$ & 8.404 & $0.364^{* * *}$ & 8.206 & $0.374^{\star * *}$ & 9.219 \\
\hline & TEA $_{i t-1}$ & 0.005 & 0.967 & $0.029^{* * *}$ & 3.116 & $0.030^{* * *}$ & 1.992 & $0.030^{* * *}$ & 3.262 \\
\hline & $\Delta \mathrm{F}_{i t}$ & $0.040^{\star * *}$ & 6.796 & $0.028^{\star * *}$ & 3.407 & $0.028^{\star * *}$ & 4.505 & $0.025^{\star * *}$ & 3.335 \\
\hline & $\Delta \mathrm{R} \& \mathrm{D}_{i t}$ & $0.143^{* * *}$ & 4.642 & $0.088^{\star * *}$ & 2.517 & $0.065^{\star * *}$ & 2.855 & $0.087^{\star * *}$ & 2.355 \\
\hline \multicolumn{2}{|c|}{$\begin{array}{l}\text { Determinant residual } \\
\text { covariance }\end{array}$} & $2.58 \mathrm{E}-11$ & & $3.08 \mathrm{E}-11$ & & $3.10 \mathrm{E}-11$ & & $3.20 \mathrm{E}-11$ & \\
\hline \multicolumn{2}{|c|}{$\begin{array}{l}\text { Akaike Information } \\
\text { Criteria }\end{array}$} & -4143.609 & & -4104.461 & & -4103.030 & & -4096.014 & \\
\hline \multicolumn{2}{|c|}{ Number of observations } & 221 & & 221 & & 221 & & 221 & \\
\hline
\end{tabular}

Notes: ${ }^{*},{ }^{* *}$ and ${ }^{* *}$ denote significance level at $10 \%, 5 \%$ and $1 \%$, respectively; ${ }^{(1)}$ The White method is used in order to guarantee the efficiency of the estimators; ${ }^{(2)}$ The Hausman test for endogeneity. Null hypothesis: exogenity. Statistics are $6.444^{\star * *}, 2.940$ and $10.760^{* * *}$ for 1 st, 2 nd and 3rd equation, respectively.

impact on the economic activity of the regions. In summary, regions with higher levels of human capital endowment, $\mathrm{R} \& \mathrm{D}$ expenditure and creation of new businesses will have higher growth rates which explain the divergence in the economic growth of regions.

From the estimation of equation (8b), presented in Table 3, it can be seen that the creation of new businesses per inhabitant in each region depends on R\&D expenditure per capita, on entrepreneurial activity rate and on TFP. The estimated coefficients indicate that the generation of new businesses per inhabitant depends positively on the effort made by each region in the promotion of knowledge, measured through $\mathrm{R} \& \mathrm{D}$ expenditure per capita. The data also indicates that the rate of activity of the business and the point in the economic cycle are other factors that contribute positively to the generation of new businesses in the region. The positive impact of the economic cycle on the creation of businesses implies that the push effect or refugee effect is rejected. The outcomes obtained from the system corroborate the existence of the Schumpeter effect in the sense that the creation of businesses is favoured by the entrepreneurial environment of the region and, in turn, the creation of businesses generates economic growth (Aubry et al., 2015).

Finally, the results of equation (8c), presented in Table 3, reveal that entrepreneurial activity in the different regions depends on $R \& D$ expenditure per capita, on business dynamics 
quantified through the generation of new businesses per capita and on a factor of inertia captured through its own past value entrepreneurial activity. The estimated coefficients indicate that entrepreneurial activity depends positively on the effort made by each region in the promotion of knowledge, measured through $\mathrm{R} \& \mathrm{D}$ expenditure per capita. It also indicates that business dynamics measured through the increase of businesses per capita is another factor that contributes positively to the entrepreneurial activity of each region. At the same time, entrepreneurial activity presents a significant inertia.

\section{Conclusions}

This paper analyses the interrelation between entrepreneurial capital and productive efficiency, with an analysis of the importance of business dynamics and entrepreneurial activity in explaining the differences in economic growth that exist between the Spanish regions. To this end, a multi-equation model is specified and estimated which reflects the interrelationship between business dynamics, entrepreneurship and productive efficiency. In relation to the data used, it should be noted that both the entrepreneurial activity and the number of new businesses were used as indicators of entrepreneurial capital.

The multi-equation model formulated presents some advantages over the usual single-equation model, from an econometric point of view, as it allows the collection of the interrelations that exist in the variables and avoids possible problems of endogeneity. The estimation method used provides consistent and more efficient estimators than alternative models. In addition, the estimators obtained through the different methods confirm their robustness.

The results corroborate that both the entrepreneurial activity and the creation of businesses have a positive effect on productive efficiency. In addition, the stock of human capital, the promotion of knowledge and the degree of technological innovation act as catalysts that favourably influence economic activity and, in particular, productive efficiency. In fact, the importance of the promotion of knowledge in economic growth and in productive efficiency is further emphasized. It is also worth noting that the dynamic part of the model shows the existence of high inertia in the rate of entrepreneurial activity in different regions. The estimations obtained suggest the existence of a Schumpeter effect within the framework of the Spanish regions, thus rejecting the push effect. The positive impact of the economic cycle on the creation of businesses shows that the push effect, which suggests that unemployment stimulates the creation of businesses, is rejected. In addition, the creation of businesses generates economic growth, according to the Schumpeter effect.

The differences in the promotion of knowledge, the quality of the workforce, the entrepreneurial level and the business fabric of the regions explain the divergences in the growth and economic development of the regions. Regional advances in efficiency require the promotion of knowledge which depends on the local emphasis on R\&D and education of the workforce.

From the empirical evidence extracted from the model, it can be concluded that as an economic policy measure authorities should encouraged investment in $\mathrm{R} \& \mathrm{D}$. It is clear that the regions that invest the most in knowledge are more efficient and also show greater en- 
trepreneurial activity and business dynamism, both of which favour economic growth. In addition, investment in human capital is also essential, particularly in education, in order to increase cognitive skills to achieve a quality workforce. The promotion of entrepreneurship may also be important in reducing regional differences. Moreover, policies to support new businesses and increase survival of existing companies should lead to greater regional efficiency. These policies should include financial help for viable projects or fiscal exemptions for new projects in their start-up years.

One limitation of this paper is that it does not review the quality of the labour force in the regions. Future research could therefore extend to analysis of the impact of the quality of education in the regions on the differences in economic performance.

\section{References}

Acs, Z. (2006). How is entrepreneurship good for economic growth? Innovations: Technology, Governance, Globalization, 1(1), 97-107. https://doi.org/10.1162/itgg.2006.1.1.97

Acs, Z. J., Estrin, S., Mickiewicz, T., \& Szerb, L. (2018). Entrepreneurship, institutional economics, and economic growth: an ecosystem perspective. Small Business Economics, 51(2), 501-514. https://doi.org/10.1007/s11187-018-0013-9

Aghion, P. (2017). Entrepreneurship and growth: lessons from an intellectual journey. Small Business Economics, 48(1), 9-24. https://doi.org/10.1007/s11187-016-9812-z

Aubry, M., Bonnet, J., \& Renou-Maissant, P. (2015). Entrepreneurship and the business cycle: the "Schumpeter" effect versus the "refugee" effect - a French appraisal based on regional data. The Annals of Regional Science, 54(1), 23-55. https://doi.org/10.1007/s00168-014-0645-x

Audretsch, D. B. (2007). Entrepreneurship capital and economic growth. Oxford Review of Economic Policy, 23(1), 63-78. https://doi.org/10.1093/oxrep/grm001

Audretsch, D. B., \& Keilbach, M. (2004). Entrepreneurship capital and economic performance. Regional Studies, 38(8), 949-959. https://doi.org/10.1080/0034340042000280956

Audretsch, D. B., \& Keilbach, M. (2008). Resolving the knowledge paradox: knowledge-spillover entrepreneurship and economic growth. Research Policy, 37(10), 1697-1705. https://doi.org/10.1016/j.respol.2008.08.008

Audretsch, D. B., Keilbach, M., \& Lehmann, E. E. (2006). Entrepreneurship and economic growth. New York: Oxford University Press. https://doi.org/10.1093/acprof:oso/9780195183511.001.0001

Audretsch, D. B., \& Peña-Legazkue, I. (2012). Entrepreneurial activity and regional competitiveness: an introduction to the special issue. Small Business Economics, 39(3), 531-537. https://doi.org/10.1007/s11187-011-9328-5

Banco de España. (2015). Business dynamics in Spain: characteristics, determinants and implications (Annual Report 2015, 93-121). Madrid.

Barro, R. J. (1991). Economic growth in a cross section of countries. Quarterly Journal of Economics, 106(2), 155-173. https://doi.org/10.2307/2937943

Barro, R. J. (2001). Human capital and growth. American Economic Review, 91(2), 12-17. https://doi.org/10.1257/aer.91.2.12

Barro, R. J., \& Lee, J. W. (1993). International comparisons of educational attainment. Journal of Monetary Economics, 32(3), 363-394. https://doi.org/10.1016/0304-3932(93)90023-9

Barro, R. J., \& Sala-i-Martin, X. (2004). Economic growth (2nd ed.). Cambridge, Massachusetts, London, England: The MIT Press.

Becker, G. S. (1975). Human capital: a theoretical and empirical analysis, with special reference to education. National Bureau of Economic Research (NBER), New York. 
Bjornskov, C., \& Foss, N. (2013). How strategic entrepreneurship and the institutional context drive economic growth. Strategic Entrepreneurship Journal, 7(1), 50-69. https://doi.org/10.1002/sej.1148

Blanco-Mesa, F., Gil-Lafuente, A. M., \& Merigó, J. M. (2018). New aggregation operators for decisionmaking under uncertainty: an applications in selection of entrepreneurial opportunities. Technological and Economic Development of Economy, 24(2), 335-357.

https://doi.org/10.3846/20294913.2016.1212744

Braunerhjelm, P., Acs, Z. J., Audretsch, D. B., \& Carlsson, B. (2010). The missing link: knowledge diffusion and entrepreneurship in endogenous growth. Small Business Economics, 34(2), 105-125. https://doi.org/10.1007/s11187-009-9235-1

Callejón, M., \& Segarra, A. (1999). Business dynamics and efficiency in industries and regions: the case of Spain. Small Business Economics, 13(4), 253-271. https://doi.org/10.1023/A:1008015317323

Carree, M. A., \& Thurik, R. (2008). The lag structure of the impact of business ownership on economic performance in OECD countries. Small Business Economics, 30(1), 101-110. https://doi.org/10.1007/s11187-006-9007-0

Carree, M. A., \& Thurik, R. (2010). The impact of entrepreneurship on economic growth. In Z. J. Acs \& D. B. Audretsch (Eds.), Handbook of entrepreneurship research (pp. 557-594). New York: Springer. https://doi.org/10.1007/978-1-4419-1191-9_20

Cobb, C., \& Douglas, P. (1928). A theory production. The American Economic Review, 18(1), 139-165.

Coe, D. T., \& Helpman, E. (1995). International R\&D spillovers. European Economic Review, 38(5), 859-887. https://doi.org/10.1016/0014-2921(94)00100-E

Cuadrado, P., \& Moral, E. (2016). El crecimiento potencial de la economía española (No. 1603). Banco de España, Documentos Ocasionales, Madrid.

European Commission. (2017). Country report Spain 2017 including an in-depth review on the prevention and correction of macroeconomic imbalances. (Commission Staff Working Document). Retrieved from https://ec.europa.eu/info/sites/info/files/2017-european-semester-country-report-spain-en. pdf

Erken, H., Donselaar, P., \& Thurik, R. (2018). Total factor productivity and the role of entrepreneurhip. Journal Technology Transfer, 43(16), 1493-1521. https://doi.org/10.1007/s10961-016-9504-5

Fritsch, M. (2008). How does new business formation affect regional development? Introduction to the special issue. Small Business Economics, 30(1), 1-14. https://doi.org/10.1007/s11187-007-9057-y

Fritsch, M., \& Schroeter, A. (2011). Why does the effect of new business formation differ across regions. Small Business Economics, 36(4), 383-400. https://doi.org/10.1007/s11187-009-9256-9

Griliches, Z. (1998). R\&D and productivity: the econometric evidence. Chicago: University of Chicago Press. https://doi.org/10.7208/chicago/9780226308906.001.0001

Griliches, Z., \& Lichtenberg, F. R. (1984). R\&D and productivity growth at the industry level: is there still a relationship? In Z. Griliches (Ed.), R\&D, patents, and productivity (pp. 465-496). Chicago: Chicago University Press and NBER.

González-Pernía, J. L., \& Peña-Legazkue, I. (2015). Export-oriented entrepreneurship and regional economic growth. Small Business Economics, 45(3), 505-522. https://doi.org/10.1007/s11187-015-9657-x

Guellec, D., \& Van Pottelsberghe de la Potterie, B. P. (2004). From R\&D to productivity growth: do the institutional settings and the source of funds of R\&D matter? Oxford Bulletin of Economics and Statistics, 66(3), 353-378. https://doi.org/10.1111/j.1468-0084.2004.00083.x

Hanushek, E. A. (2012). Education quality and economic growth. In B. Miniter (Ed.), The 4 percent solution: unleashing the economic growth America needs (Chapter 16, pp. 227-239). New York: Cross Business.

Holtz-Eakin, D., \& Kao, C. (2003). Entrepreneurship and economic growth: the proof is in the productivity (Working paper, No. 50). Syracuse: Center for Policy Research. https://doi.org/10.2139/ssrn.1809885 
Jacobs, B., Nahuis, R., \& Tang, P. J. G. (2002). Sectoral productivity growth and R\&D spillovers in the Netherlands. De Economist, 150(2), 181-210. https://doi.org/10.1023/A:1015696202835

Kato, M., \& Honjo, Y. (2015). Entrepreneurial human capital and the survival of new firms in high- and low-tech sectors. Journal of Evolutionary Economics, 25(5), 925-957. https://doi.org/10.1007/s00191-015-0427-3

Koellinger, P. D., \& Thurik, A. R. (2012). Entrepreneurship and the business cycle. Review of Economics and Statistics, 94(4), 1143-1156. https://doi.org/10.1162/REST_a_00224

Krugman, P. (1994). The age of diminished expectations. Cambridge, MA: The MIT Press.

Lucas, R. (1988). On the mechanics of economic development. Journal of Monetary Economics, 22(1), 3-42. https://doi.org/10.1016/0304-3932(88)90168-7

Lucas, R. (1993). Making a miracle. Econometrica, 61(2), 251-272. https://doi.org/10.2307/2951551

Mincer, J. (1984). Human capital and economic growth. Economics of Education Review, 3(3), 195-205. https://doi.org/10.1016/0272-7757(84)90032-3

OECD. (2008). A framework for addressing and measuring entrepreneurship. Paris: OECD Publishing.

Prieger, J. E., Bampoky, C., Blanco, L. R., \& Liu, A. (2016). Economic growth and the optimal level of entrepreneurship. World Development, 82, 95-109.

https://doi.org/10.1016/j.worlddev.2016.01.013

Rico, P., \& Cabrer-Borrás, B. (2019). Entrepreneurship, firms creation and regional performance. European Journal of Management and Business Economics (in press). https://doi.org/10.1108/EJMBE-07-2018-0077

Rodriguez-Pose, A., \& Comptour, F. (2012). Do clusters generate greater innovation and growth? An analysis of European regions. The Professional Geographer, 64(2), 211-231. https://doi.org/10.1080/00330124.2011.583591

Romer, P. M. (1986). Increasing returns and long-run growth. The Journal of Political Economy, 94(5), 1002-1037. https://doi.org/10.1086/261420

Sevilir, M. (2010). Human capital investment, new firm creation and venture capital. Journal of Financial Intermediation, 19(4), 483-508. https://doi.org/10.1016/j.jfi.2009.08.002

Solow, R. M. (1956). A contribution to the theory of economic growth. The Quarterly Journal of Economics, 70(1), 65-94. https://doi.org/10.2307/1884513

Schumpeter, J. (1934). Theory of economic development: an inquiry into profits, capital, credit, interest, and the business cycle. Cambridge, MA: Harvard University Press.

Thurik, A. R., Carree, M. A., Van Stel, A., \& Audretsch, D. B. (2008). Does self-employment reduce unemployment? Journal of Business Venturing, 23(6), 673-686. https://doi.org/10.1016/j.jbusvent.2008.01.007

Van Praag, C. M., \& Van Stel, A. (2013). The more business owners, the merrier? The role of tertiary education. Small Business Economics, 41(2), 335-357. https://doi.org/10.1007/s11187-012-9436-X

Van Praag, C. M., \& Versloot, P. H. (2007). What is the value of entrepreneurship? A review of recent research. Small Business Economics, 29(4), 351-382. https://doi.org/10.1007/s11187-007-9074-x

Van Stel, A. J., Carree, M. A., \& Thurik, A. R. (2005). The effect of entrepreneurial activity on national economic growth. Small Business Economics, 24(3), 311-321. https://doi.org/10.1007/s11187-005-1996-6

Vila, L., Cabrer-Borras, B., \& Pavia, J. M. (2015). On the relationship between knowledge creation and economic performance. Technological and Economic Development of Economy, 21(4), 539-556. https://doi.org/10.3846/20294913.2013.876687

Wennekers, A. R. M., \& Thurik, A. R. (1999). Linking entrepreneurship and economic growth. Small Business Economics, 13(1), 25-55. https://doi.org/10.1023/A:1008063200484 